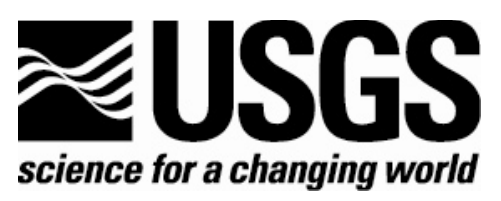

\title{
Comments on Potential Geologic and Seismic Hazards Affecting Coastal Ventura County, California
}

By Stephanie L. Ross ${ }^{1}$, David M. Boore ${ }^{1}$, Michael A. Fisher ${ }^{1}$, Arthur D. Frankel ${ }^{3}$, Eric L. Geist ${ }^{1}$, Kenneth W. Hudnut ${ }^{2}$, Robert E. Kayen ${ }^{1}$, Homa J. Lee ${ }^{1}$, William R. Normark ${ }^{1}$, and Florence L. Wong ${ }^{1}$

Open-File Report 2004-1286

2004

Any use of trade, firm, or product names is for descriptive purposes only and does not imply endorsement by the U.S. Government

${ }^{1}$ Menlo Park, Calif.

${ }^{2}$ Pasadena, Calif.

${ }^{3}$ Golden, Colo.

U.S. Department of the Interior

U.S. Geological Survey 


\section{Executive Summary}

This report examines the regional seismic and geologic hazards that could affect proposed liquefied natural gas (LNG) facilities in coastal Ventura County, California. Faults throughout this area are thought to be capable of producing earthquakes of magnitude 6.5 to 7.5 , which could produce surface fault offsets of as much as 15 feet. Many of these faults are sufficiently well understood to be included in the current generation of the National Seismic Hazard Maps; others may become candidates for inclusion in future revisions as research proceeds.

Strong shaking is the primary hazard that causes damage from earthquakes and this area is zoned with a high level of shaking hazard. The estimated probability of a magnitude 6.5 or larger earthquake (comparable in size to the 2003 San Simeon quake) occurring in the next 30 years within 30 miles of Platform Grace is 50-60\%; for Cabrillo Port, the estimate is a 35\% likelihood. Combining these probabilities of earthquake occurrence with relationships that give expected ground motions yields the estimated seismic-shaking hazard. In parts of the project area, the estimated shaking hazard is as high as along the San Andreas Fault. The combination of longperiod basin waves and LNG installations with large long-period resonances potentially increases this hazard.

Other hazards that need to be considered include:

- The potential for earthquake-induced liquefaction of wet and loose sandy material and several other potential causes of instability should be addressed as portions of the proposed projects may be developed on artificial fill. Such fill generally performs poorly during earthquakes if it was not properly engineered. Other portions may be developed on naturally deposited sediments with similarly poor performance during earthquakes.

- High-resolution bathymetric mapping of the Santa Barbara Channel has revealed the remains of a number of very large submarine landslides. However, we cannot fully assess the hazard of smaller landslides without higher resolution data; therefore, because submarine slope failure hazards exist, surveys for pipeline routes should include highresolution multibeam bathymetric imagery and slope stability analysis.

- All of the proposed pipelines from Cabrillo Port cross the delta of the Santa Clara River, a large undersea pile of sediment cut by a series of steep marine canyons. This would expose planned pipelines to hazards from turbidity currents and debris flows.

- The coastal region of Ventura and Santa Barbara Counties has been impacted by tsunamis, 20 feet or more feet, from a variety of sources in the past and, thus, hazards from future tsunamis could potentially affect proposed LNG sites. Tsunamis can be generated by very large magnitude earthquakes distant from the site or from local submarine earthquakes and landslides near the site.

Additional studies that would help reduce the uncertainty in our hazards assessments include the following:

- Collecting sediment cores offshore, to date past earthquakes and determine fault slip rates, to improve estimates of the likelihood of future earthquakes 
- Detailed mapping of soil and sediment layers in targeted coastal regions to develop a chronology of large prehistoric tsunamis and determine the potential for ground failure and liquefaction

- Offshore high-resolution multibeam bathymetric data to locate active faults on the seafloor and identify past landslides

- Utilization of marine seismic reflection data, collected by private industry along the west coast in the 1970's and 1980's for oil and gas exploration, to improve our knowledge of the location and subsurface geometry of offshore faults (and hence their earthquake potential). The USGS is currently involved in efforts to rescue these data.

\section{Introduction}

In a letter to the U.S. Geological Survey (USGS) dated June 25, 2004, Representative Lois Capps (CA 23rd district) requested advice on geologic hazards that should be considered in the review of two proposed liquefied natural gas (LNG) facilities offshore Ventura County, CA (Figure 1). In this report, we address the questions raised in her letter and her request for advice on any additional studies that might be needed to evaluate the proposed LNG facilities. The report is based on previously compiled, publicly available data and did not involve additional field studies or site-specific investigations. We have considered hazards posed to the offshore facilities Cabrillo Port (moored, http://www.cabrilloport.ene.com) and Platform Grace (on an existing oildrilling platform, http://www.crystalenergyllc.com), to their onshore distribution installations, and to the proposed pipeline routes that connect them.

These facilities are being proposed in a region of known geologic hazards that arise from both the potential for strong earthquakes and geologic processes related to the high rate of sediment transport and accumulation in the offshore environment. The probability of a damaging earthquake (considered here as magnitude 6.5 or greater) in the next 30 years within about 30 miles $(50 \mathrm{~km})$ of the two proposed locations ranges from 30 to $60 \%$. Earthquakes of this magnitude are capable of producing strong shaking, surface fault offsets, liquefaction phenomena, landslides, underwater turbidity currents and debris flow avalanches, and tsunamis. Local geologic conditions may further aggravate these hazards. For example, some of the onshore portions of the proposed pipelines would cross materials with a high susceptibility to liquefaction. Offshore sections of pipelines also risk rupture from seabed earthquake fault rupture as well as submarine landslides. These hazards should be considered as part of the evaluation of the suitability of the proposed sites, as well as during any future design review process.

This brief report outlines the geologic hazards that need to be considered, but is not intended to provide an extensive discussion of each of the identified geologic hazards or how they might affect the proposed facilities. In particular, we have not made any attempt to review proposed engineering plans as this is beyond the scope of our expertise. 


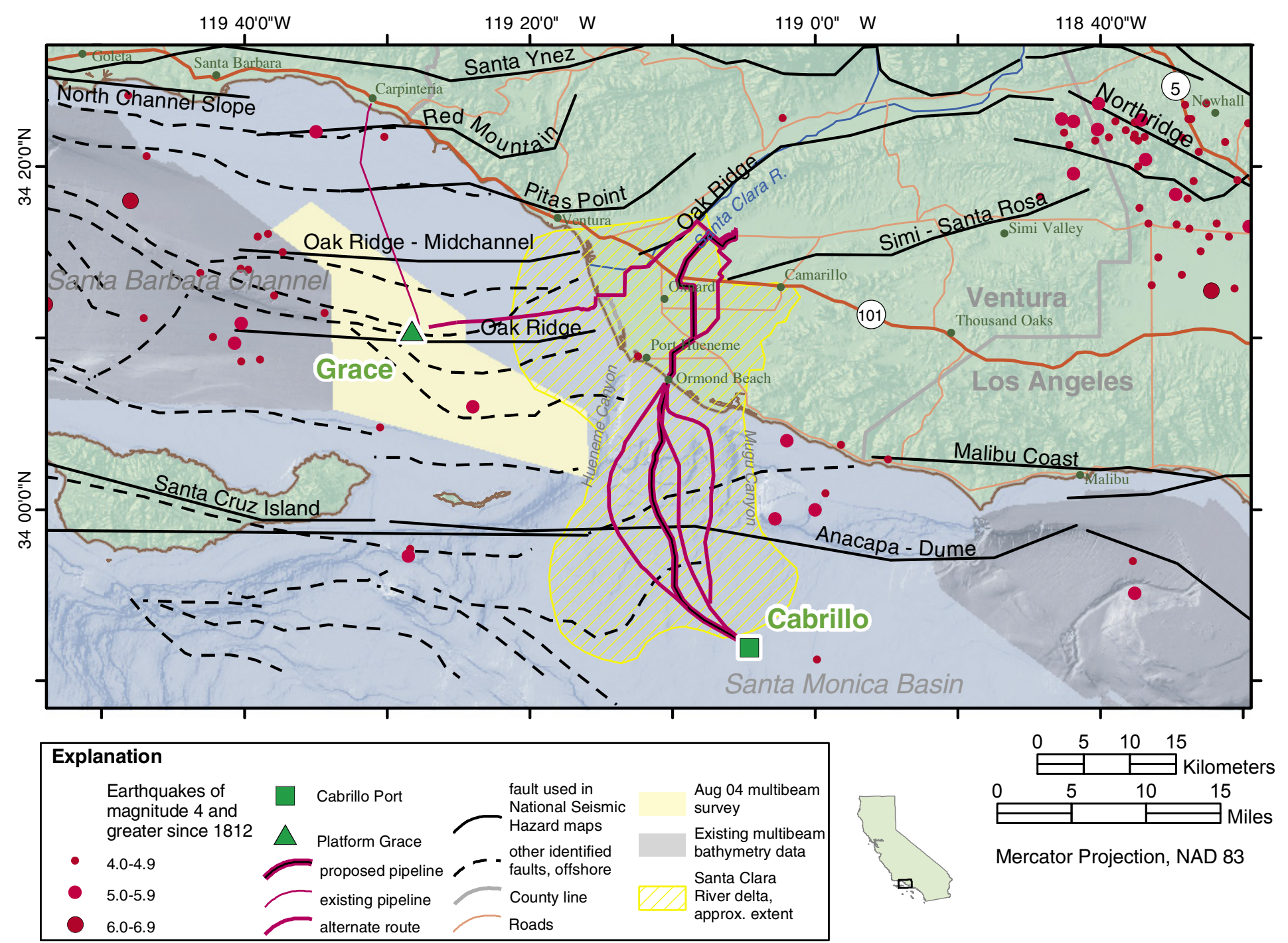

Figure 1. Map showing faults (Petersen and others, 1996; USGS, 2004a), earthquake epicenters (SCEC, 2004; USGS 2004b), delta of Santa Clara River and related drainages (Normark and others, 1998), and extent of offshore multibeam bathymetric data in relation to proposed liquefied natural gas facilities. Additional offshore faults after Sorlein and others (2000). 
If a more extensive hazard analysis is required, some of the issues raised here will be difficult to resolve without additional data. Collection of high-resolution bathymetric data in the project areas would help to resolve uncertainties about the hazard posed by small- to medium-sized landslides that potentially threaten the proposed pipelines. These studies would also help us better locate the surface traces of faults and determine their potential for rupturing the seafloor in earthquakes. In addition, collecting cores of sediments near offshore faults would help improve estimates of earthquake probabilities.

A more complete understanding of other potential hazards will require a much more thorough analysis of existing data. In particular, extensive seismic reflection data covering offshore Ventura County was gathered by the oil exploration industry over the past 30 years. These data would be invaluable for assessing the location, geometry and earthquake potential of the offshore faults and the hazards they might pose to facilities. These critical data could not be collected today because environmental restrictions make it impossible to conduct seismic reflection surveys in these areas. The USGS is currently working with industry to safeguard and archive these data and make them available to the broad research and consulting community. However, additional effort could speed the collection and interpretation of the relevant data.

\section{Regional Earthquake History}

In the relatively short time we have records of earthquake observations (since the early $19^{\text {th }}$ century), the faults in this region have produced several notable earthquakes (Weber and Kiessling, 1975; 1978; Ellsworth, 1990). In 1812, an earthquake of about magnitude (M) 7 occurred, probably in the Santa Barbara Channel. This event severely damaged the mission in Ventura (Mission San Buenaventura), and created a damaging tsunami throughout the region (Townley and Allen, 1939). In 1857, a large earthquake (about M 8) ruptured 200 miles of the inland San Andreas Fault, from Cholame (near Paso Robles) to Wrightwood. This event, known as the great Fort Tejon earthquake, also severely damaged Mission San Buenaventura. Earthquakes in the Santa Barbara Channel in 1925 (M 6.3), 1941 (M 5.5), and 1978 (M 5.1) caused some damage in Ventura (fallen chimneys, broken plate glass, surface cracks in buildings) (Bailey, 1925; Townley and Allen, 1939). The 1933 M 6.4 Long Beach earthquake (located 60 miles away) caused similar damage in the Ventura area. In 1973, an earthquake offshore of Point Mugu (M 5.2) caused widespread damage in the Oxnard area, including some structural damage to buildings (Lander, 1973). The 1994 M 6.7 Northridge earthquake caused widespread minor damage in coastal Ventura County (Dewey and others, 1995).

All of these earthquakes are the result of large-scale earth processes in which the Pacific plate slides northwestward relative to the North American plate at about 2 inches/year. This plate motion results in horizontal slip (primarily on the San Andreas "strike-slip" fault) as well as a component of compression that has created the series of east-west trending "thrust" faults with vertical motion that are responsible for the prominent mountain ranges and intervening valleys situated between Santa Monica and Santa Barbara. Although slower moving than the strikeslip faults of the San Andreas system, these numerous thrust faults account for over half of the significant earthquakes that occurred in southern California during the past century, including 
the damaging 1971 M 6.6 San Fernando, 1994 M 6.7 Northridge, and 2003 M 6.5 San Simeon earthquakes.

The historical earthquake record in southern California only covers about 200 years, so potential seismic damage is not limited to what has already been experienced at any given location. For example, the 1999 M 7.1 Hector Mine earthquake in the Mojave Desert occurred on a fault that geologists determined had not ruptured in more than 30,000 years.

\section{What are the locations of active faults in proximity to each site and what potential hazards could result from ground rupture?}

Figure 1 shows the locations of numerous faults that may pose hazards throughout this region. The thick black lines are faults used in the USGS National Seismic Hazard Maps (http:// eqhazmaps.usgs.gov/; Frankel and others, 1996 and 2002; Petersen and others, 1996). These maps are produced by the USGS every 3 to 5 years and are the basis for seismic provisions in both the International Building Code and the International Residential Code. The faults shown in Figure 1 were determined to pose a quantifiable seismic hazard by a consensus of USGS, California Geological Survey, and outside experts. To fall into this category, they must have evidence of fault slip during the past 1.6 million years (a short time in geologic history) as well as a scientifically established rate of fault slip or a history of past earthquakes from evidence such as trenches excavated across faults. In general, the fault traces are better known and documented for onshore than for offshore faults. Therefore, we also show (in dashed black lines, Figure 1) recognized offshore faults that are not currently included in the National Seismic Hazard Maps and represent the result of additional research, e.g. Sorlien and others (2000); these faults may be included in future updates of the National Maps as more information on them is developed.

All faults shown on Figure 1 have the potential to produce M 6.5 or greater earthquakes that would result in locally strong ground shaking and some combination of ground-surface breaks, liquefaction of near surface sediments both onshore and offshore, landslide triggering of both coastal bluffs and underwater slopes, and generating tsunamis. These effects have occurred as the result of past earthquakes in this region and thus are expected to occur in future earthquakes.

The maximum magnitude of an earthquake is related to fault length: the longer the fault, the larger the potential earthquake can be (Wells and Coppersmith, 1994). For example, the Oak Ridge Fault offshore, which, as shown on the National Seismic Hazard Maps, runs near Platform Grace and parallel to a proposed pipeline connecting Platform Grace to the Southern California Gas Company facility; this fault is estimated to produce earthquakes as great as M 7.1. In comparison, the much longer Anacapa-Dume Fault, near Cabrillo Port, is thought to be capable of producing earthquakes as great as M 7.5 (for comparison, the great San Francisco 1906 earthquake was M 7.8). As we learn more, connections between different faults are sometimes found, increasing total fault length and the sizes of potential earthquakes. The offshore region is more difficult to study, but acquiring additional high-resolution ("swath") bathymetric data and seismic reflection data will help define fault structure, and sediment cores may help estimate fault slip rates and the times of past earthquakes. 
The offshore facilities and the offshore and on land pipeline routes will be subject to hazard from surface fault breaks during future large earthquakes on crossing or nearby faults. The faults in this region are thought to be capable of producing earthquakes as great as M 6.5 to 7.5 , which could produce surface offsets as large as 15 feet. New techniques, in conjunction with knowledge of prehistoric earthquake activity on these faults, make it possible to calculate the probabilities, amounts and locations of surface rupture affecting the proposed facilities and pipelines. However, these methods have not been widely applied yet, and, for many of the faults in the study area, little information exists, so such calculations would be highly uncertain unless additional studies could also be conducted on prehistoric faulting.

The offshore portion of the Oak Ridge Fault runs very close to Platform Grace (Greene and others, 1978; Dahlen, 1992; Shaw and Suppe, 1994; Kamerling and Nicholson, 1996; Kamerling and others, 1998; Sorlien and others, 2000). The onshore portion of the Oak Ridge Fault appears to be the westward continuation of the thrust fault that caused the 1994 M 6.7 Northridge earthquake (Yeats and Huftile, 1995). Onshore, the Oak Ridge Fault slips at about 1.6 inches per decade, on a long-term average. Offshore, the National Seismic Hazard Maps distribute this slip across the more southerly Oak Ridge Fault (estimated at 1.2 inches per decade) and the Oakridge-Midchannel Fault trend estimated (at 0.4 inches per decade). Faultrelated compression may also be transferred to other nearby faults and folds in the Santa Barbara Channel (Yeats and others, 1988; Huftile and Yeats, 1995). During a large earthquake, surface rupture would not likely occur on the offshore Oak Ridge Fault because it is primarily a "blind" thrust fault; that means its main strands are below ground and do not clearly reach the seafloor. However, significant surface deformation, such as warping, and offset across mapped subsidiary structures (shown on figure 1), poses a significant hazard. A pipeline extending northward from Platform Grace to Carpenteria crosses the Oakridge-Midchannel Fault trend, the Red Mountain Fault Zone, and the Pitas Point Fault Zone (Yeats and others, 1987; Yerkes and others, 1987; Kamerling and Sorlien, 1999).

The moored Cabrillo Port would connect to shore via a pipeline across a major east-west fault system that includes, among others, the Santa Cruz Island Fault, the Anacapa-Dume Fault, and the Malibu Coast Fault (Ellsworth and others, 1973; Stierman and Ellsworth, 1976; Dibblee, 1982; Dibblee and Ehrenspeck, 1993; Drumm, 1992). Although only the onshore segment of the Malibu Coast Fault was included in the National Seismic Hazard Maps, an offshore extension of this fault identified in other studies is shown in Figure 1 (Greene and Kennedy, 1986; Sorlien, 1999; Sorlien and others, 2000). This fault system comprises numerous fault strands, including one or more deep thrust faults that might produce large earthquakes. As previously noted, the Anacapa-Dume Fault has the potential for producing the largest earthquakes in the region, up to M 7.5.

\section{What potential hazards could result from shaking?}

Strong shaking is the primary hazard that causes damage from earthquakes and this area has been zoned with a high level of seismic shaking hazard. The goal of the USGS National 
Seismic Hazard Mapping effort is to quantify the level of shaking that may occur with sufficient frequency that it should be considered in the development of building codes or the design of specific projects. For example, some of the maps show the amount of earthquake shaking with a $2 \%$ chance of being exceeded in 50 years. Thus, if a project is built to withstand this level of shaking, but no more, there would be a $2 \%$ chance of incurring damage during the next 50 years.

While the USGS provides estimates of the ground-shaking hazard for any probability level, engineers and public policy experts must decide on the appropriate probability level to be used in the design of a facility or project. This probability level is determined by the acceptable level of risk, which will vary depending on the consequences of structural failure. For example, the U.S. Nuclear Regulatory Commission now specifies a hazard level for nuclear power plants that has a probability 40 times stricter than the $2 \%$ in 50-year hazard level.

Figure $2 \mathrm{a}$ is a map of the estimated probability of having a magnitude 6.5 or larger earthquake within 30 miles of each location on the map in the next 30 years. For the Platform Grace site, the estimated probability is about 50 to $60 \%$. The probability is about $35 \%$ for the moored Cabrillo Port site. The probabilities of moderate and large earthquakes increase inland, with probabilities of $60 \%$ or more along the on land pipeline route north of Ormond Beach. Thus, there is a high likelihood of having earthquakes somewhere in this region with M 6.5 or higher in the next 30 years.

Figure $2 b$ shows an expanded view of one of the USGS National Seismic Hazard Maps (Frankel and others, 2002). This map shows the peak acceleration of the shaking as a percent of the acceleration of gravity for the $2 \%$ in 50 years hazard level for a site on "firm rock" (as opposed to softer sediments). These maps represent a conservative estimate of the shaking hazard. For areas filled with soft sediment, such as coastal valleys, the expected shaking levels will be higher. The proposed facilities are in areas of high hazard from earthquake ground shaking. For example, near Cabrillo Port there is a $2 \%$ chance that there will be ground shaking of $60 \%$ or more of the acceleration of gravity $(60 \% \mathrm{~g})$ in the next 50 years. Higher values (around $85 \% \mathrm{~g}$ ) are found for the Platform Grace site and $120 \% \mathrm{~g}$ is calculated along the proposed pipeline route northeast of Oxnard. The latter value is similar to the hazard along much of the San Andreas Fault. To put these numbers into context, the highest horizontal accelerations observed during the Northridge earthquake (M 6.7) were about $90 \%$ of the acceleration of gravity. Thus, there is a $2 \%$ chance in the next 50 years of much of this area experiencing ground motions equal to or higher than the highest ground motions observed during the Northridge earthquake. If a stricter risk level is chosen with lower probability, then the hazard assessment ground motions will increase.

There are additional factors that could increase the estimated ground-shaking hazard to the proposed facilities. For example, structures are prone to damage from shaking at their resonant period (the duration in seconds at which the structure preferentially oscillates when disturbed). Offshore platforms and storage tanks are large structures that can have relatively long resonant periods, in excess of 1 second. Compounding the earthquake hazard is the existence of "basin" waves, which are not included in the National Seismic Hazard Maps. Basin waves are seismic waves that echo inside the sediment that fills underground valleys in the harder bedrock, producing amplified shaking at long periods (e.g. Joyner, 2000). If these periods match the 


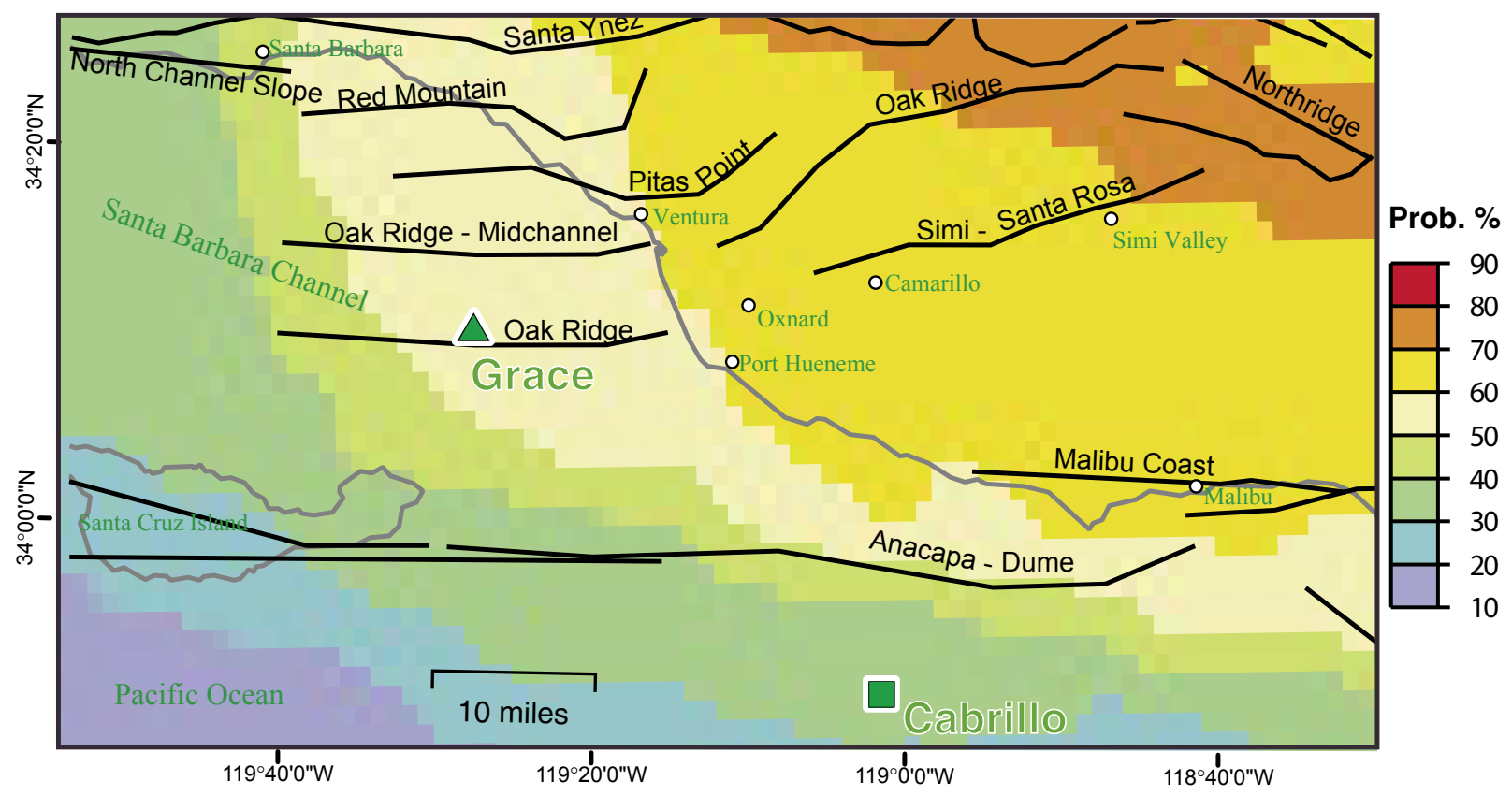

Figure 2a. Percent probability of a magnitude 6.5 or greater earthquake within 30 years and $50 \mathrm{~km}$ (31 miles). Only faults used in the National Seismic Hazard Maps are shown (Petersen and others, 1996).

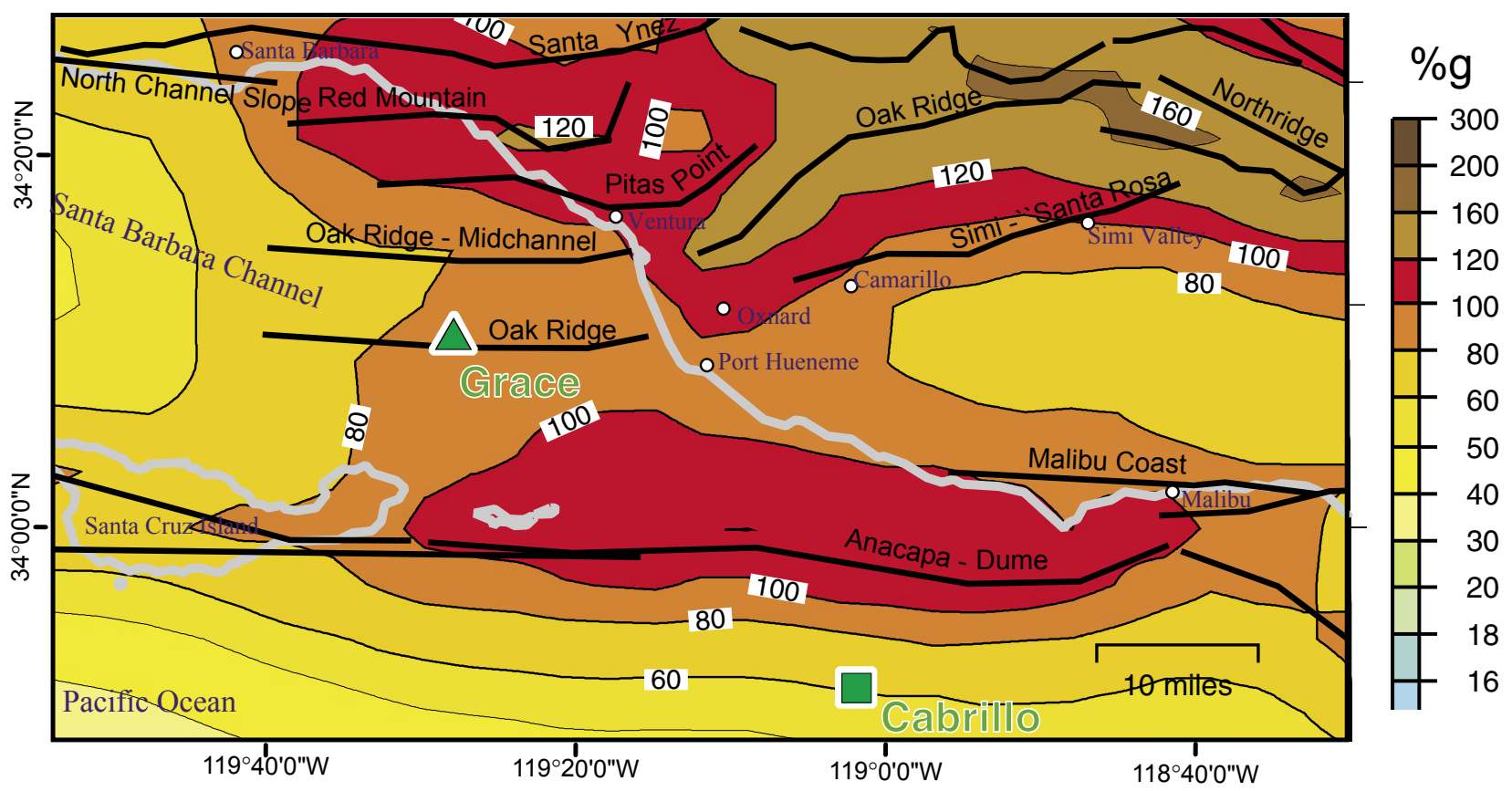

Figure 2b. Earthquake ground motion (peak acceleration) as a percent of the acceleration of gravity with a $2 \%$ chance of being exceeded in 50 years. Data and faults from USGS National Seismic Hazard Map, firm rock site condition (Frankel and others, 2002). 
resonant frequencies of the structures, then the hazard increases for these structures. For example, an earthquake recording from a site offshore of Long Beach of waves traversing the Los Angeles Basin contains substantial energy at periods as long as 7 seconds (Boore, 1999); therefore, large structures offshore of Long Beach with resonant periods in this range would face greater hazards than represented in the hazard maps. Structures in the Santa Monica Basin might similarly be subject to basin wave effects. Another concern for structures with long resonant periods is that they can be influenced by large earthquakes at relatively great distance from the site; this effect is also not well represented in the maps. For example, a repeat of the 1857 Fort Tejon earthquake on the San Andreas Fault would produce long period motion in the project area. If the proposed LNG facilities contain platforms, tanks or pipelines with long resonant periods, then these factors must be considered to determine if they are applicable to the specific sites.

It is important to emphasize the uncertainties in the parameters used to make these hazard assessments. The locations and subsurface geometry of the offshore faults are poorly known. The slip rates of these faults are also poorly constrained, so that estimates of earthquake recurrence rates are poorly determined. In the hazard maps, alternative models of faulting are used to reflect differing views by various geoscientists. For example, it is not known how much of the slip on these faults occurs during earthquakes and how much may be due to slow movement on faults that does not produce shaking.

\section{Which specific earthquake hazards should be considered in more detail? (In answering, we also discuss related geologic hazards)}

\section{Engineering Foundation Stability, Ground Failure, and Liquefaction}

The potential for earthquake-induced liquefaction of wet and loose sandy material and several other potential causes of instability should be addressed for this project. Portions of the proposed projects may be developed on coastal areas of artificial fill, which generally performs poorly during earthquakes if not properly engineered. For example, liquefaction of artificial fills in the coastal town of Oceano, California, caused significant damage to buildings and lifelines despite being 30 miles from the 2003 M 6.5 San Simeon earthquake. Other portions of the proposed projects may be developed on naturally deposited sediments with similarly poor performance during earthquakes. For example, sandy continental shelf deposits in the Klamath Delta area of far northern California liquefied and flowed during a 1980 M 7.0 earthquake. The flow failures produced a 3 to 6 foot high scarp. Such failures could also occur on the continental shelf of the Santa Barbara Channel and might impact offshore pipelines. Thus, it is necessary to assess the ability of underlying geologic materials and fills to stably support the foundations of buried and surface engineered structures.

When soils liquefy during strong shaking, horizontal displacements as large as tens of feet may occur and are especially damaging to buried utilities and unsupported foundations. The venting of ground water as it is expelled from the liquefied sands can unevenly displace and tilt foundations, affecting both buried and surface structures. In addition, large areas that are only 
slightly above sea level could lose elevation and be submerged. Clayey soils do not liquefy but may also be subject to large displacements due to earthquake shaking. Earthquake-induced displacements and cracking may also occur at boundaries between different soils and between soil and rock. Geologically young clay soils, like bay mud, may consolidate slowly when subjected to loads from new structures, causing these structures to settle. This process involves the slow expulsion of pore water and can occur over decades.

The onshore section of the pipeline from Platform Grace to the distribution facilities may require special care in engineering and design due to liquefaction and ground failure hazards. This is because the proposed onshore pipeline parallels both the Oak Ridge Fault and the Santa Clara River channel for 6 miles. This entire onshore section of the pipeline runs through recently deposited sediments that are identified by the California Geological Survey for their potential liquefaction hazard during seismically induced shaking. The Santa Clara River channel is particularly susceptible to liquefaction and other forms of ground failure, and is also close to the mapped trace of the Oak Ridge Fault, making it particularly important to address these hazards there.

For all of these aspects of foundation stability, routine and well-developed site investigation techniques are available to characterize the physical properties of soils, and widely accepted geotechnical engineering models exist to evaluate potential deformation hazards.

\section{Submarine Landsides}

Multibeam bathymetric imaging of the Santa Barbara Channel has shown the remains of a number of very large submarine landslides (Eichhubl and others, 2002). The largest is located offshore of Goleta and 18 miles west of Platform Grace; the "Goleta Slide" measures 8.5 miles long and 6.5 miles wide, and probably occurred within the past 6000 years. Mathematical modeling indicates that when this landslide occurred, it could have generated a tsunami with a height at the coast ranging from 6 to 65 feet (Borrero and others, 2001). There are also buried remains of other landslides. The estimated recurrence interval for these very large landslides is about 15,000 years (Lee and others, 2004).

Several medium-sized submarine landslide deposits also exist in Santa Barbara Channel; the best known is the Gaviota Slide (Lee and others, 2004). This slide, 28 miles west of Platform Grace, measures over a mile on each side and likely occurred in the last 300 years. It may have been triggered by the 1812 Santa Barbara earthquake.

The area near Platform Grace has not been mapped using high-resolution bathymetric ("multibeam") techniques, so the existence of small to medium-sized submarine landslide deposits cannot be discerned. This platform does lie on a 150-m high slope near a submerged channel, so there is some possibility of a slope failure at the site. Multibeam mapping and slope stability analysis for this site should be conducted to identify previous failures and determine the risk of future failures. Currently available low-resolution bathymetric data show that pipelines connecting Platform Grace to the shore pass through generally flat seafloor areas that are 
probably unlikely locations for large submarine landslides. However, we cannot fully assess the hazard of smaller landslides without higher resolution data. Therefore, because submarine slope failure hazards may still exist, surveys for pipeline routes should include multibeam bathymetric imagery and slope stability analysis.

\section{Turbidity Currents and Debris Flows}

All of the proposed pipelines extending on land from Cabrillo Port cross the delta of the Santa Clara River (Dahlen and others, 1990), exposing them to hazards from mass movements of loose sediment and rock slurries (known as turbidity currents and debris flows). The delta, a large undersea pile of sediment, fed by the Santa Clara River, is cut by five north-south canyons on the delta slope. The Hueneme Canyon, largest and most active of the five, is the major conduit for turbidity currents and debris flows (Normark and others, 1998; Piper and others, 1999). Figure 1 shows Hueneme and Mugu Canyons, the outermost of the five.

Some river systems, including the Santa Clara River, carry substantial sediment in suspension during major flood events, and commonly this slurry of fresh river water and sediment is denser than sea water (Warrick and Milliman, 2003). When this occurs, gravity pulls the slurry downslope, forming high-speed turbulent flows known as hyperpycnal flows, which are a type of turbidity current (Mulder and Syvitski, 1995). Turbidity currents, especially on steeper slopes in submarine canyons, move with such speed and power that the only comparable on land processes are the catastrophic volcanic flows that rush down the flanks of volcanoes during explosive eruptions. A turbidity current in the Laurentian Fan, off of Nova Scotia, broke submarine telecommunications cables and is thought to have traveled at 45 miles per hour (see review of turbidity current processes in Normark and Piper, 1991). The Santa Monica Basin has less relief than the Laurentian Fan, so turbidity currents there would not reach the same speed. Reynolds (1987) documents a turbidity current event in the Santa Monica Basin about 100 years ago that transported more than a million cubic yards of sediment at speeds of 2 miles per hour. This event is suggested to have resulted from the southern California flood of 1884. A much larger turbidity current that transported more than 10 million cubic yards of sediment occurred about 200 years ago; it transported coarser (larger grain-size) sediment and its velocity must have been substantially greater (Malouta and others, 1981). This earlier event is suggested to have been generated as a result of sediment failure during the 1812 Santa Barbara earthquake.

Turbidity currents capable of transporting sand-sized sediment more than 35 miles from the Hueneme Canyon to the basin floor have occurred about every 200 years on average during the last 3000 years (Normark and McGann, 2004). Triggered commonly by earthquakes and large storms, these flows are typically 150 feet high (Piper and others, 2003). The proposed site for the Cabrillo Port facility is directly in the path of such energetic flows. Several of the smaller canyons on the delta slope east of Hueneme Canyon are filled by deposits of past debris flows up to 35 feet thick (Piper and others, 1999). These debris flows were probably generated by seismic shaking from nearby earthquakes. All of the proposed pipeline routes to move gas from Cabrillo 
Port to the coast cross one or more of the canyons and channels on the young and still active submarine delta slope.

Improved assessment of the hazards from these turbidity currents and debris flows will require research to answer the following questions. How stable are the deep channels cut into the submarine delta? How often do large storms, such as those related to El Niño events, create hyperpycnal flows? How often do earthquakes cause debris flows and turbidity currents? How often do submarine landslides cause debris flows and turbidity currents? How can pipeline design protect against hazards from thick, energetic turbidity currents and muddy debris flows?

\section{What is the vulnerability of offshore LNG facilities to tsunamis generated by nearby offshore earthquakes or potentially large coastal bluff landslides?}

The coastal region of Ventura and Santa Barbara Counties has been impacted by tsunamis from a variety of sources in the past (Lander, Lockridge, and Kozuch, 1993) and, thus, hazards from future tsunamis could potentially affect proposed LNG sites. A tsunami is a series of waves whose height increases as water depth shallows. In the deep, open ocean, their height will only be a few feet and they are unrecognizable. However, they grow as they approach shore, and they can reach heights exceeding 100 feet in coastal waters. Hazards from tsunamis include: (1) runup where tsunami waves wash ashore at heights above normal wave action, and (2) strong currents that can affect marine terminals.

Tsunamis can be generated by very large magnitude earthquakes distant from the site (termed far-field tsunamis) or from local submarine earthquakes and landslides near the site (termed local tsunamis). An example of a far-field or trans-oceanic tsunami is the one generated by the 1964 M 9.2 Alaska earthquake that caused considerable damage along much of the west coast of the United States (Lander, Lockridge, and Kozuch, 1993). In southern California, this tsunami was observed as multiple surges as high as 10 feet accompanied by very strong currents. The latter caused most of the damage in ports and harbors, with smaller boats capsizing and larger ships ramming into docks and piers. In Los Angeles harbor, an oil tanker ripped out a 175-foot section of dock. A local M 5.2 earthquake in 1930 was followed by a tsunami with 20 feet of runup in Santa Monica, which caused a fatality in Redondo Beach (Lander, Lockridge, and Kozuch, 1993); the tsunami was probably caused by a submarine landslide triggered by the earthquake.

The inter-agency National Tsunami Hazard Mitigation Program (NTHMP), which includes the National Oceanic and Atmospheric Administration (NOAA), the USGS, the Federal Emergency Management Agency (FEMA), the National Science Foundation (NSF), and the five western Pacific states, is dedicated to mitigating tsunami hazards in the U.S. (http://www.pmel.noaa. gov/tsunami-hazard/). The NTHMP develops tsunami inundation maps, showing regions near the ocean that are likely to be flooded during a major tsunami (González and others, 2001). They are used primarily to determine evacuation routes and in long-term planning for vulnerable coastal communities. Preliminary inundation maps have been completed for Los Angeles, Ventura, and Santa Barbara counties, and are in development for San Luis Obispo 
County (Eisner, Borrero, and Synolakis, 2001). In addition, a FEMA study has been undertaken jointly by the Marine Facilities Division of the California State Lands Commission and the University of Southern California to develop standards and guidelines for marine terminals in Los Angeles, Ventura and Orange Counties (Synolakis, Eskijian, and others, 2003). 100-year and 500-year tsunami probabilities were estimated in a 1974 U.S. Army Corps of Engineers Report (see Eisner, Borrero, and Synolakis, 2001) for Ventura at 10.5 feet and 21.7 feet, respectively. These estimates, however, need considerable refinement given the current state of knowledge of tsunami generation and dynamics and are the subject of an ongoing FEMA-sponsored pilot study for the National Flood Insurance Program that involves members of the NTHMP.

Improving the tsunami hazard assessments will require making detailed inundation maps for engineering assessment of specific marine facilities. This includes determining accurate wave heights and currents at higher spatial resolution (165 feet or less) than used for the current inundation maps. Tsunami probabilities also need to be refined in line with current understanding of tsunami generation and modeling capabilities.

\section{Please describe the scope of any additional studies that may be needed for evaluation of both proposals.}

Beyond the issues raised above, additional research is needed to reduce uncertainties in the hazard assessments:

- Global Positioning System (GPS) measurements to provide the overall rate of tectonic compression across the region in order to constrain the expected rate of large earthquakes.

- Geophysical and sonar studies to identify, map, and characterize the underwater traces of the faults.

- Determining the chronology of prehistoric earthquakes and fault slip rates through trenching studies on land and sediment coring offshore. Knowledge of the rates of these past earthquakes reduces the uncertainty in the earthquake probabilities.

- Detailed mapping of soil and sediment layers in targeted coastal regions to develop a chronology of large prehistoric tsunamis and determine the potential for ground failure and liquefaction.

- High-resolution topographic mapping using airborne lasers (LIDAR) to locate active faults on land, and possibly to map subtle landscape features indicative of blind faults. The LIDAR data are also used to identify places on these faults suitable for trenching studies.

- Offshore high-resolution multibeam bathymetric data to locate active faults on the seafloor and identify past landslides. Figure 3 a shows the existing multibeam bathymetric coverage in this region; the area around Platform Grace is scheduled to be collected in August, 2004 (a joint USGS-Minerals Management Service project) but important gaps will remain over Cabrillo Port and parts of the pipeline routes. 

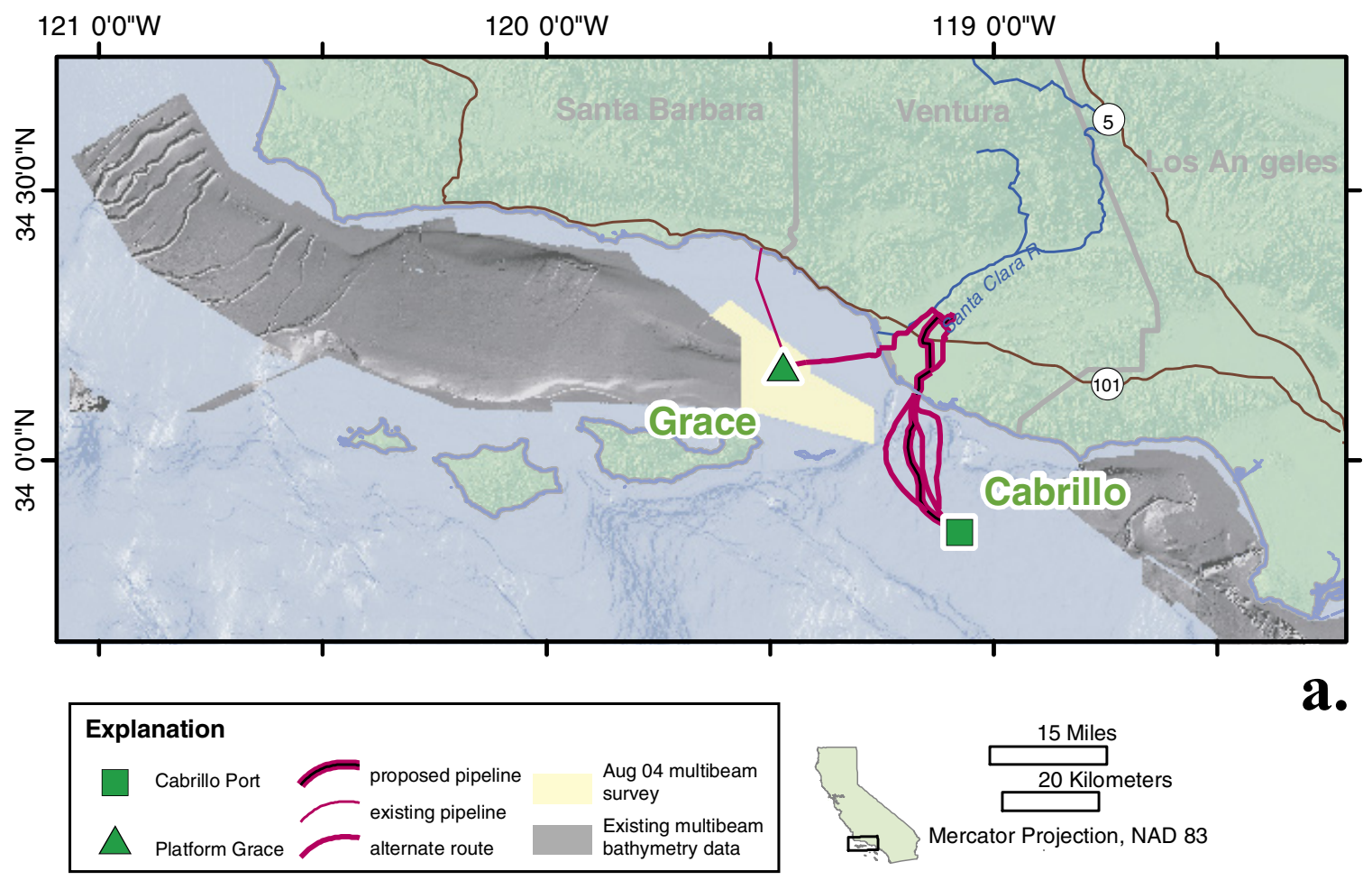

a.

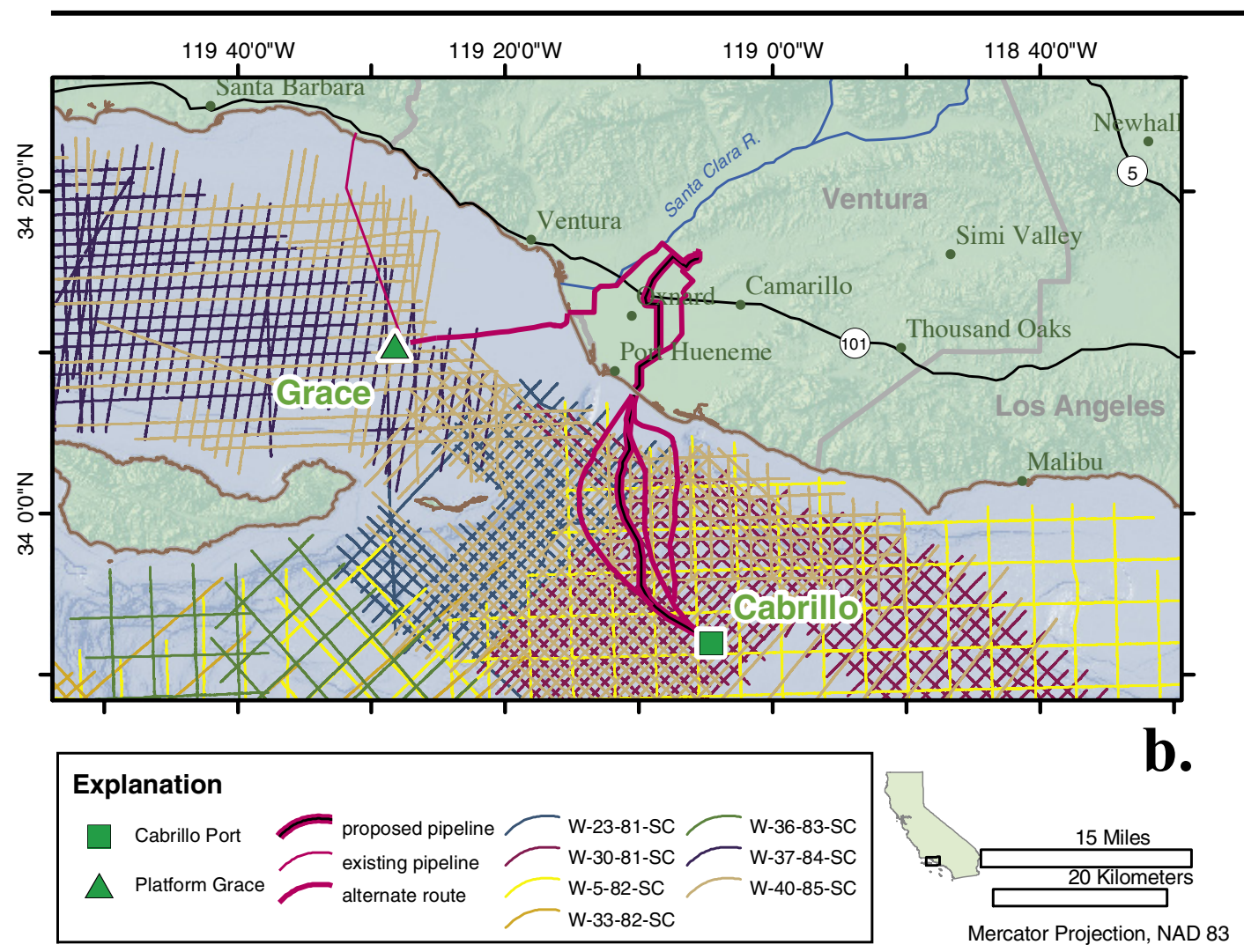

Figure 3 a. Coverage of existing multibeam bathymetric data in study area (MBARI, 2001; Gardner and Dartnell, 2002). b. Tracklines of seismic reflection data collected by Western Geco (USGS, 2004c). Shaded relief basemap generated from NOAA (2004) data. 
- Utilization of marine seismic reflection data, collected by private industry along the west coast in the 1970's and 1980's for oil and gas exploration, to improve our knowledge of the location and subsurface geometry of offshore faults (and hence their earthquake potential). The USGS is currently involved in efforts to rescue these data (Figure 3b and http://walrus.wr.usgs.gov/NAMSS/), which is critical because they are irreplaceable due to new environmental restrictions on the use of marine seismic sources such as airguns. The rescue efforts cost much less than $1 \%$ of what it would cost to collect the data again and will insure that this priceless resource is available to the public.

\section{Acknowledgments}

This document was greatly improved through reviews by Samuel Johnson and Mary Lou Zoback, and by additional advice from David Applegate, James Devine, William Ellsworth, Lucile Jones, Andrew Michael, and Bruce Rogers. Stephen Harmsen provided the earthquake probability map, Figure 2a. We thank Michael Diggles for formatting the web version and Carolyn Donlin for additional web support.

\section{References}

Boore, D.M., 1999, Basin waves on a seafloor recording of the 1990 Upland, California, earthquake: Implications for ground motions from a larger earthquake, Bull. Seism. Soc. Am, v. 89, p. 317-324.

Borrero, J. C., Dolan, J. F., Synolakis, C. E., 2001. Tsunamis within the eastern Santa Barbara Channel. Geophy. Res. Let., 28, pp.643-646.

Dahlen, M. Z., 1992, Sequence Stratigraphy, depositional history, and middle to late Quaternary sea levels of the Ventura shelf, California: Quaternary Research, v. 38, p. 234-245.

Dahlen, M. Z., Osborne, R. H., and Gorsline, D. S., 1990, Late Quaternary history of the Ventura mainland shelf, California: Marine Geology, v. 94, p. 317-340.

Dewey, J. W., Dengler, L., and Reagor, B. G., 1995, Spatial variations of intensity in the Northridge earthquake, in The Northridge, California, Earthquake of 17 January, 1994, ed. Woods, M.C., and Seiple, W. R., California Division of Mines and Geology Special Publication 116, p. 39-46.

Dibblee, T. W., 1982, Geology of the Santa Monica Mountains and Simi Hills, southern California, in Fife, D. L., and Minch, J. A., eds., Geology and mineral wealth of the California Transverse Ranges: Santa Ana, CA, South Coast Geological Society, Inc., p. 94-130.

Dibblee, T. W., and Ehrenspeck, H. E., 1993, Geologic map of the Point Dume quadrangle Los Angeles and Ventura Counties, California: Dibblee Geological Foundation Map \#DF-48, p. 1 sheet.

Drumm, P. L., 1992, Holocene displacement of the central splay of the Malibu Coast fault zone, Latigo Canyon, Malibu, in Pipkin, B. W., and Proctor, R. J., eds., Engineering Geology Practice in southern California, Special Publication 4, Association of Engineering Geologists: Belmont, CA, Star Publishing Company, p. 247-254. 
Eichhubl, P., Greene, H.G. and N. Maher, N., 2002. Physiography of an active transpressive margin basin; high-resolution bathymetry of the Santa Barbara Basin, southern California continental borderland. Mar. Geol., 184, 95-120.

Eisner, R.K., Borrero, J.C., and Synolakis, C.E., 2001, Inundation maps for the State of California, in International Tsunami Symposium 2001, Seattle, WA, p. 67-81.

Ellsworth, 1990, Earthquake history, 1769-1989, in The San Andreas Fault System, California, ed. Wallace, R.E., USGS Professional Paper 1515, p. 153-188.

Ellsworth, W. L., Campbell, R. H., Hill, D. P., Page, R. A., Alewine, R. W., Hanks, T. C., Heaton, T. H., Hileman, J. A., Kanamori, H., Minster, B., and Whitcomb, J. H., 1973, Point Mugu, California, earthquake of 21 February 1973 and its aftershocks: Science, v. 182, p. 1127-1129.

Frankel, A., Mueller, C., Barnhard, T., Perkins, D., Leyendecker, E., Dickman, N., Hanson, S., and Hopper, M., 1996. National seismic-hazard maps: documentation June 1996, USGS Open-file Report 96-532, 110 pp.

Frankel, A., Petersen, M., Mueller, C., Haller, K., Wheeler, R., Leyendecker, E., Wesson, R., Harmsen, S., Cramer, C., Perkins, D., and Rukstales, K., 2002, Documentation for the 2002 update of the national seismic hazard maps: U.S. Geological Survey Open-File Report 02-420, 39 pages, http://pubs.usgs.gov/of/2002/ofr-02-420/

Gardner, J. V., and Dartnell, P., 2002, Multibeam Mapping of the Los Angeles, California Margin: U.S. Geological Survey Open-file Report 02-162, http://geopubs.wr.usgs.gov/ open-file/of02-162/

González, F.I., Titov, V.V., Mofjeld, H.O., Venturato, A.J., and Newman, J.C., 2001, The NTHMP Inundation Mapping Program, in International Tsunami Symposium 2001, Seattle, WA, p. 29-54.

Greene, H. G., and Kennedy, M. P., 1986, Geology of the mid-southern California continental margin, California Continental Margin Geologic Map Series, Area 2, California Department of Conservation, Division of Mines and Geology, 4 sheets

Greene, H. G., Wolf, S. C., and Blom, K. G., 1978, The marine geology of the eastern Santa Barbara Channel with particular emphasis on the ground water basins offshore from the Oxnard plain, southern California: U.S. Geological Survey Open-file report 78-305, p. $104 \mathrm{p}$.

Huftile, G. J., and Yeats, R. S., 1995, Convergence rates across a displacement transfer zone in the western Transverse Ranges, Ventura basin, California: Journal Geophysical Research, v. 100, p. 2043-2067.

Joyner, W.B., 2000, Strong motion from surface waves in deep sedimentary basins, Bull. Seism. Soc. Am, v. 90, p. S95--S112.

Kamerling, M., and Nicholson, C., 1996, The Oak Ridge fault and fold system, eastern Santa Barbara Channel, California: Southern California Earthquake Center Annual Report, v. 11, p. C26-C30.

Kamerling, M. J., Sorlien, C., and Alex, C. M., 1998, Map restoration of a Quaternary horizon across the Oak Ridge fault, offshore and onshore Ventura Basin, California: American Association Petroleum Geologists Bulletin, v. 82, p. 850.

Kamerling, M. J., and Sorlien, C. C., 1999, Quaternary slip and geometry of the Red Mountain and Pitas Point-North Channel faults, California: Eos, Transactions, American Geophysical Union, v. 80(46), p. 1003. 
Lander, J.F., ed., 1973, Seismological Notes: January - February 1973. Bulletin of the Seismological Society of America, Vol. 63, No. 5, pp. 1841-1846.

Lander, J.F., Lockridge, P.A., and Kozuch, M.J., 1993, Tsunamis affecting the west coast of the United States 1806-1992: U.S. Department of Commerce, National Oceanic and Atmospheric Administration, NGDC Key to Geophysical Records Documentation No. 29, 242 p.

Lee, H.J., Normark, W.R., Fisher, M.A., Greene, H.G., Brian D. Edwards, B.D.; and Locat, J., 2004. Timing and Extent of Submarine Landslides in Southern California, Offshore Technology Conference Paper Number 16744, Houston, TX.

Malouta, D. N., Gorsline, D. S., and Thornton, S. E., 1981, Processes and rates of Recent (Holocene) basin filling in an active transform margin: Santa Monica Basin, California Continental Borderland. Journal Sedimentary Petrology, v. 51, p. 1077-1096.

Monterey Bay Aquarium Research Institute (MBARI), 2001, Santa Barbara Multibeam Survey: MBARI Digital Data Series No. 4, http://mbari.org/data/mapping/SBBasin/default.htm

Mulder, T., and Syvitski, J. P. M., 1995, Turbidity currents generated at mouths of rivers during exceptional discharges to the world oceans, Journal of Geology, v. 103, p. 285-299.

National Oceanic and Atmospheric Administration (NOAA), 2004, Coastal Relief Model http:// www.ngdc.noaa.gov/mgg/coastal/coastal.html

Normark, W. R., and McGann, M., in press, Late Quaternary deposition in the inner basins of the California Continental Borderland: Part A. Santa Monica Basin, U.S. Geological Survey Scientific Investigations Report, 2004-XXXX.

Normark, W. R. and Piper, D. J. W., 1991, Initiation processes and flow evolution of turbidity currents: implications for the depositional record, in Osborne, R. H. (ed), From Shoreline to Abyss, SEPM Special Publication No. 46, p. 207-230.

Normark, W. R., Piper. D. J. W., and Hiscott, R. N., 1998, Sea level controls on the textural characteristics and depositional architecture of the Hueneme and associated submarine fan systems, Santa Monica Basin, California, Sedimentology, v. 45, p. 53-70.

Petersen, M. D., Bryant, W. A., Cramer, C. H., Cao, T., Reichle, M. S., Frankel, A. D., Lienkaemper, J. J., McCrory, P. A., and Schwartz, D. P., 1996, Probabilistic Seismic Hazard Assessment for the State of California, DMG Open-File Report 96-08 and USGS Open-File Report 96-706, 64 p., http://pubs.er.usgs.gov/pubs/ofr/ofr96706

Piper, D. J. W., Hiscott, R. N., and Normark, W. R., 1999, Outcrop-scale acoustic facies analysis and latest Quaternary development of Hueneme and Dume submarine fans, offshore California, Sedimentology, v. 46, p. 47-78.

Piper, D. J. W., Normark, W. R., and McGann, M., 2003, Variations in accumulation rate of late Quaternary turbidite deposits in Santa Monica Basin, offshore southern California: Eos Trans. AGU, 84(46), Fall Meet. Suppl., Abstract OS52B-0916.

Reynolds, S., 1987, A recent turbidity current event, Hueneme fan, California: reconstruction of flow properties: Sedimentology, v.34, p.129-137.

Shaw, J. H., and Suppe, J., 1994, Active faulting and growth folding in the eastern Santa Barbara Channel, California: Geological Society America Bulletin, v. 106, p. 607-626.

Sorlien, C. C., 1999, Rapid subsidence and south propagation of the active Santa Monica Mountains-Channel Islands thrust: Annual Report Southern California Earthquake Center, v. Available on the Internet at: http://www.scec.org/research/99research/, p. 5 p. 
Sorlien, C. C., Gratier, J. P., Luyendyk, B. P., Hornafius, J. S., and Hopps, T. E., 2000, Map restoration of folded and faulted late Cenozoic strata across the Oak Ridge fault, onshore and offshore Ventura basin, California: Geological Society America Bulletin, v. 112, p. 1080-1090.

Southern California Earthquake Center Data Center (SCEC), 2004, Southern California catalogs: http://www.data.scec.org/catalog_search/

Stierman, D. J., and Ellsworth, W. L., 1976, Aftershocks of the February 21, 1973 Point Mugu, California earthquake: Bulletin Seismological Society America, v. 66, p. 1931-1952.

Synolakis, C.E., Eskijian, M., Borrero, J.C., and McCarthy, D., 2003, NEES tsunami "product" example: Standards and guidelines for construction of coastal structures [abs.]: Eos, Transactions American Geophysical Union, v. 84, p. F804-F805.

Townley, S. D., 1939, Earthquakes in California, 1769 to 1928. Bulletin of the Seismological Society of America, Vol. 29, No. 1, pp. 21-252.

Ulrich, F. P., 1941, The Imperial Valley Earthquakes of 1940. Bulletin of the Seismological Society of America, Vol. 31, No. 1, pp. 13-31, Figures 3, 7b, 10, 11, 14.

U.S. Geological Survey, 2004a, Quaternary Faults and Fold Database of the United States: http:// qfaults.cr.usgs.gov/

U.S. Geological Survey, 2004b, California Earthquake History 1769-Present: http://pasadena. wr.usgs.gov/info/cahist_eqs.html

U.S. Geological Survey, 2004c, National Archive of Marine Seismic Surveys, WesternGeco Southern California Tracklines: http://walrus.wr.usgs.gov/NAMSS/wgtrackline_scs.html

Warrick, J. A., and Milliman, J. D., 2003, Hyperpycnal sediment discharge from semiarid southern California rivers: implications for coast sediment budgets. Geology, v. 31, p. 781-784.

Weber, F. H., and Kiessling, E. W., 1975, General features of seismic hazards of Ventura County, California, in Seismic Hazards Study of Ventura County, California, California Division of Mines and Geology Open-File Report 76-5 L A, p. 8-218.

Weber, F. H., and Kiessling, E. W., 1978, Historic earthquakes effects in Ventura County, California Geology, v. 31, p. 103-107.

Wells, D. L., and Coppersmith, K. J., 1994, New empirical relationships among magnitude, rupture length, rupture width, rupture area, and surface displacement: Bulletin Seismological Society America, v. 84, p. 974-1002.

Willis, Bailey, 1925, A Study of the Santa Barbara Earthquake of June 29, 1925. Bulletin of the Seismological Society of America, Vol. 15, No. 4, pp. 255-278.

Yeats, R. S., 1988, Late Quaternary slip rate on the Oak Ridge fault, Transverse Ranges, California: Implications for seismic risk: Journal of Geophysical Research, v. 93, p. 12,137-12,150.

Yeats, R. S., and Huftile, G. J., 1995, The Oak Ridge fault system and the 1994 Northridge earthquake: Nature, v. 373, p. 418-420.

Yeats, R. S., Huftile, G. J., and Grigsby, F. B., 1988, Oak Ridge fault, Ventura fold belt, and the Sisar decollement, Ventura basin, California: Geology, v. 16, p. 1112-1116.

Yeats, R. S., Lee, W. H. K., and Yerkes, R. F., 1987, Geology and seismicity of the eastern Red Mountain Fault, Ventura County: U. S. Geological Survey Professional Paper 1339, p. 161-167. 
Yerkes, R. F., Sarna-Wojcicki, A. M., and LaJoie, K. R., 1987, Geology and Quaternary deformation of the Ventura area: in Recent reverse faulting in the Transverse Ranges, California: U.S. Geological Survey Professional Paper 1339, p. 169-178. 